Anita Pavković, Ph.D.

University of Zagreb, Faculty of Economics and Business Zagreb, Zagreb, Croatia apavkovic@efzg.hr

Robert Hrgović, Student

University of Zagreb, Faculty of Economics and Business Zagreb, Zagreb, Croatia rhrgovic@net.efzg.hr

August Cesarec, Teaching and Research Assistant

University of Zagreb, Faculty of Economics and Business Zagreb, Zagreb, Croatia acesarec@efzg.hr

\title{
IMPACT OF NON-PERFORMING LOANS ON BANKS' LOAN PORTFOLIO AND ECONOMIC GROWTH IN THE REPUBLIC OF CROATIA AND BOSNIA AND HERCEGOVINA
}

Received: October 20, 2018

Accepted: December 20, 2018

Original scientific paper

\begin{abstract}
Bank loans are the most important source of the banks' income and profitability. The structure of loan portfolio, such as maturity, currency, type of interest rate or credited sector, is also highly significant for banks' business performance. In the latest global financial crisis, quality of the loans sharply deteriorated, thus increasing the percentage of non-performing loans in banks' balance sheets and causing major problems in business activity for many banks. The events emphasized the importance and potential impact of non-performing loans not just on banks, but on the whole economy and society.

The aim of this article is to analyse determinants of non-performing loans, future challenges and possible solutions of high NPL ratios in Bosnia and Herzegovina and Croatia. Multiple regression analysis was conducted to determine strength and coefficient of the independent micro and macro variables (GDP growth rate, unemployment rate, Consumer Price Index, amount of bank loans and value of stock exchange indexes) on the level of non-performing loans. Obtained results indicate that GDP growth rates are significant in both countries but with opposite impact. Additionally, unemployment rate is significant in Bosnia and Herzegovina and amount of loans in Croatia.
\end{abstract}

Despite current economic expansion, banks are still slightly reluctant in 
approving loans, alert of the potential growth of the non-performing loans and its effect on banking performance. In recent years, the level of NPL ratio started decreasing in both countries, mostly due to the selling or writing off loans by the commercial banks, but this level is still higher than in the comparable countries. Therefore, more effort is needed to further improve loan portfolio and enforce economic growth, with possible measures being better banks' NPL management, improvement of insolvency procedures and more transparent justice system.

Keywords: Non-performing loans, banks, banking loans, Croatia, Bosnia and Herzegovina

JEL: E44, G21

\section{INTRODUCTION}

Quality of the commercial banks' assets is an exceptionally important determinant of the entire economy. Not only does it show the business success and performance of the financial sector, but it can determine the speed and dynamic of the development at the level of entire economy by providing support and the most important source of funds, i.e. bank loans for various sectors of the economy. The well-regulated financial sector is one of the key driving wheels of a modern and successful economy, which is certainly confirmed by the development trend of the financial sector. Therefore, it is imperative for the successful economic growth that the commercial banks maintain liquid and are prepared for global shocks in challenging times, as it was the last economic crisis stemming from the US real estate business model and related securities.

Above mentioned goal can only be achieved through efficient supervision and regulation of commercial banks. In the context of the Bosnia and Herzegovina and Croatia, the supervisory and regulatory bodies were built from the ground up, mostly by adoption of the good foreign practices, after the transition to the market based economic system. Also, the lack of the qualified staff in the system of planned economies was another challenge. The very fact that Croatia is a member of the European Union (EU) and strives to join European Monetary Union and that Bosnia and Herzegovina is on its way to EU accession shows the success of adjusting national bodies to contemporary regulatory and supervisory standards.

Regarding bank loans, they are still the most important component of banks' balance sheets and a key source of their income. Their quality and profitability determines the efficiency, profitability and business success of each institution, but also of the whole banking sector. But, due to the importance of banks and their role in the financial intermediation, the low quality of banks' loan portfolio, i.e. high level of non-performing loans (NPLs) triggers much wider macroeconomic 
challenges, such as increase of the systemic risk, higher funding costs, lower supply of loans and finally lower potential GDP growth or even recession (European Systemic Risk Board, 2017, 12).

As in most countries worldwide and especially in Europe, banks and banking loans are the most important sources of funds for the economic development in the Bosnia and Herzegovina and Croatia. Consequently, the quality of banking loan portfolio and percentage of the NPLs is a key prerequisite for the economic success, but also for the banks' profitability and liquidity. Preliminary data and analysis for both countries indicate much higher levels of the NPLs than the EU average, but also higher level than the other Central and Eastern European Countries (Raiffeisen Research, 2017, 19).

The aim of this article is to analyse determinants of non-performing loans, future challenges and possible solutions of high NPL ratios. Multiple regression analysis with the ratio of NPLs to total loans as a dependent variable and five independent variables (GDP growth rate, unemployment rate, Consumer Price Index, amount of bank loans and value of stock exchange indexes)were used to determine this effect. Main hypothesis of the article is that macroeconomic variables, especially GDP growth rate due to the cyclicality of banks, are key in determining the level of banks NPLs.

The rest of this paper is organised as follows. Second section reviews literature regarding levels of NPLs and their effect on the broader economy worldwide and in countries of interest. Data and the methodology are described in the third section, while section four presents the results of the model. Section five contains future challenges, possible solutions to the high NPL ratio and study limitations. Section six contains main conclusions of this paper.

\section{LITERATURE REVIEW}

Recent global financial crisis raised the importance and awareness of the NPL ratio on performance of the banking sector, but also on the whole economy due to the bank size and availability of funds for economic growth. This interaction between the economic performance and financial systems is in the focus of researchers for long time. Main theoretic studies in this field demonstrated the procyclicality of the financial systems, i.e. in the good time quality and strength of the borrowers balance sheets increases investments and growth, while the opposite occurs in the case of financial crisis (Bernanke and Gertler, 1989, 28; Bernanke et al., 1999, 1342). The authors also emphasize the importance of small and temporary shocks on the business cycle fluctuations (Kiyotaki and Moore, 1997, 211).

Many studies have researched the determinants influencing NPL ratios on the level of individual countries. In Greece, country severely affected by the financial and 
sovereign debt crisis, macroeconomic variables (GDP growth rate, unemployment, the lending rates and public debt) and quality management could have a significant impact on levels of NPLs (Louzis et al., 2012, 1025). Research for Italy demonstrates that the business cycle has a key effect on loan losses which are significant and long lasting in the recession times (Quagliariello, 2007, 137). In the US, market based financial system, analysis of the NPL determinants highlights several bank specific (capitalization liquidity and profitability) and macroeconomic (GDP growth rate, unemployment, real personal income) indicators which determine the NPL ratio (Ghosh, 2015, 93). Author also emphasizes that the statelevel economic conditions as a variable should be taken into account for the conduction of the stress test and also that non optimal levels of capital, i.e. overcapitalization enhances NPLs. On the other hand, in Spain the importance of the microeconomic individual bank level variables, such as the growth policies and managerial incentives, is proved even after the control for macroeconomic conditions (Salas and Saurina, 2002, 221). Certain authors emphasize the importance of the moral hazard of lending decisions and management risk tolerance which can cause a significant variation of loan losses across similar banks and economic conditions (Keeton and Morris, 1987, 19; Zhang et al., 2015, 58).

Studying the case of the advanced economies, analysis demonstrates that adverse macroeconomic developments, such as a GDP decline or rise of the unemployment, result in rising level of the NPL ratio (Nkussu, 2011, 20). Author also argues that high levels of NPL tend to have a negative effect on the economic growth, thus deterioration in economic activity and banking performance reinforce each other and intensify negative trends. Similarly, research that focuses on the macroeconomic determinants of NPLs across 75 countries shows that the GDP growth rates are the main driver of non-performing loans(Beck, 2011, 546). Additionally, in countries with a high degree of foreign currency lending, exchange rate depreciation may lead to the increase of NPL ratio, while a drop in stock prices could be important for stock oriented countries and markets.

In Eurozone, the importance of the macroeconomic conditions on the bank performance and level of NPLs is emphasized with the conclusion that GDP growth rates and unemployment have a strong influence on loan losses (Makri et al.,2013, 203; Dimitrios et al., 2016, 119). Authors also emphasize the importance of the management skills, risk preferences, ROE and capital adequacy ratio as an important bank specific variables determining the NPL ratio. Recently conducted meta analysis of 37 studies indicates that economic growth has a negative, while unemployment rate, inflation and interest rate mostly have a positive effect on the NPL ratio (Macháček et al., 2018, 354).

The sources and impacts of NPL ratios were also studied in Central and Eastern Europe. A study focused on the period 1998-2011concluded that macroeconomic factors have a higher impact on the NPL ratio than the bank specific factors, thus rise of the unemployment, exchange rate depreciation and higher inflation tend to 
increase NPL ratio(Klein, 2013, 20). Similar results were obtained by a research from 2007 to 2012 in which GDP, unemployment rate and inflation have a key impact on the NPL ratios in Central and Eastern Europe, with the highest and negative coefficient observed by the GDP growth rates (Škarica, 52, 2014).

Analysis of the NPL ratio in Bosnia and Herzegovina, Croatia and Serbia indicates significant and long-lasting connection between NPLs and macroeconomic factors (Kozarić and Žunić, 2017, 101). Especially emphasized contributing factors are GDP growth rate, inflation and unemployment. In Bosnia and Herzegovina, research focusing on the bank specific factors demonstrates that the increase of the risk weighted assets increases, while the increase in ratio of liquid asset to shortterm liabilities decreases NPL ratio (Kozarić and Žunić, 2015, 138). Interestingly, researches indicate contrary significance of the GDP growth ratio on NPL ratio, with the significant and insignificant impact observed for the different time periods (Agić and Jeremić, 2018, 56; Pašić and Omerbegović-Arapović, 2016, 81). In Croatia, the increase of the GDP growth rate and industrial production index have a significant effect in reducing the level of NPLs (Benazić and Radin, 2015, 85; Žiković et al., 2015, 22). Additionally, both papers conclude that effect of the macroeconomic determinants on the level of NPL is more evident in the longer periods and rather mixed in the short run.

\section{DATA AND METHODOLOGY}

\subsection{Data}

The data for this model is collected from multiple sources. Databases from the International Monetary Fund were used to obtain data for the ratio of NPLs to total loans, Consumer Price Indexes (CPIs) and GDP growth rates. All other variables were retrieved from national sources, i.e. from national central banks (amount of total loans), national stock exchanges (value of stock exchange indexes) and bureaus of statistics (registered unemployment rates - a ratio of unemployed persons to the total active population). Data was collected on the quarterly basis covering the period of 11 years from Q12007-Q42017.

All data, except the GDP growth rates, were calculated as an annual percentage changes on the quarterly levels. Therefore, the variables in the model are: $\mathrm{npl}$ (annual percentage changes in NPL ratio), cpi (annual percentage change in Consumer Price Index), gdp (real GDP growth rate), loan (annual percentage change of the amount of total banks' loans), share (annual percentage change of key stock exchange index for each country) and unpl (yearly percentage change of registered unemployment rates).

The complexity of the NPL ratio and issues is evident from the various classifications, definitions and number of days used to classify loans as the non- 
performing ones. According to the IMF, whose databases were used to obtain NPL ratios in this study, loan is classified as non-performing if payments of principal and interest are past due by at least 90 days or if interest payments equal to 90 days interest or more have been capitalized or rolled over (International Monetary Fund, 2006, 46). European Banking Authority defines non-performing exposures as exposures that have a material exposures which are more than 90 days past-due or where the debtor is assessed as unlikely to pay its credit obligation in full without realisation of collateral, regardless of the existence of any past-due amount or of the number of days past due (European Banking Authority, 2013, 13).

Recent global financial crisis exposed certain weakness in the accounting standards, especially regarding credit losses of the banks which were taken into consideration during set up and implementation of recent regulatory measures. For instance, IRFS 9, effective from January 2018, takes into consideration a more forward looking approach where model requires credit institutions to take into account the amount of expected credit losses and a trigger event is not needed to recognise credit losses (International Financial Reporting Standards, 2014, 14). Framework Basel III, beside defining default and exposure, sets up classification of exposure into grade A, B and C depending on the exposure to the risk of banks' counterparty (Bank for International Settlements, 2017,13). Similar classification of exposures is adopted in Croatia with the definition and classifications of A (A-1 and A-2 sub-categories), B (B-1, B-2 and B-3 sub-category) and C risk categories in order of better estimation of the possible credit risks (Croatian National Bank, 2017, 5).

Regarding the number of days needed to classify the loans as non-performing, the Croatian National Bank in its reporting uses a ESA2010 accounting framework that defines the loan as uncollective after the last 90 days of the maturity day, while Bosnia and Herzegovina in its statistical reporting and guidelines also highlights the time limit of 90 days (Croatian National Bank,2014, 10; Central bank of Bosnia and Herzegovina, 2017, 8).Despite this similarities, data regarding NPL ratio, its possible standardization and the results of the analysis should be taken with consideration due to the possible difference in classification and coverage, especially taking into account period of 11 years when regulatory changes and various guidelines are inevitable. Certain researches indicate various sources of heterogeneity regarding the NPLs definition in Central, Eastern and South Eastern Europe, with the more prominent ones being dealing with collateral, sub-categories of NPL and used approaches (customer vs productive) which are followed by the definitions (European Banking Coordination "Vienna" Initiative, 2012, 14).

\subsection{Methodology}

In order to observe the impact and strength of the various variables on the ratio of NPLs to total loans, multiple linear regression models (OLS) for each country were 
constructed, with the NPL ratio as an independent and all other variables as a dependent variables. The regression was carried out for Croatia and Bosnia and Herzegovina separately and obtained results were compared.

Firstly, in order to ensure stationarity of the observed variables, Augmented Dickey-Fuller Test presented in table 1 was conducted for each country. Since most of the variables were not stationary at the original level, transformation of the variables using first difference, one of the possible methods to resolve nonstationarity issues, was used in order to obtain variable stationarity (Chatfield, 2003, 49). After transformations, one variable for each county was not taken into models due to the unachieved stationarity using first differences.

Table 1. Augmented-Dickey-Fuller unit root Test for the Bosnia and Herzegovina and Croatia

\begin{tabular}{|l|l|l|l|l|}
\hline \multirow{2}{*}{ Variable } & \multicolumn{2}{|c|}{ Bosnia and Herzegovina } & \multicolumn{2}{c|}{ Croatia } \\
\cline { 2 - 5 } & \multicolumn{1}{|c|}{ Original } & First difference & Original & First difference \\
\hline NPL & -1.817476 & $-3.584539^{*}$ & -0.686768 & -3.670029 \\
\hline CPI & -4.610152 & $-3.526464^{*}$ & -2.136103 & $-2.528127^{* *}$ \\
\hline GDP & -3.152143 & -7.345888 & -2.034755 & -5.734954 \\
\hline LOAN & -7.65918 & $-1.912752^{* *}$ & -1.991981 & -5.441548 \\
\hline SHARE & -2.334611 & -4.894418 & -4.494629 & $-3.597489^{*}$ \\
\hline UNPL & -3.262735 & -5.702052 & -1.692031 & $-3.138222^{*}$ \\
\hline \multicolumn{2}{r}{ First difference values without * or ** are stationary at the $1 \%$}
\end{tabular}
significance level.

* Stationarity at the $5 \%$ significance level

** Not stationary at the $10 \%$ significance level

Source: Authors' calculation

Due to the fact that certain macroeconomic factors do not immediately impact NPL ratio and number of days needed to classify loans as non performing, lags of the dependent variables were used in the model based on the Akaike, Schwartz and Hanan-Quinn information criteria. By applying this approach, historical factors causing existing differenced in the NPL ratio are taken into account (Wooldridge, 2016, 283).Additionally, AR(1) process was used in the model to consider the effect of past value (t-1) on current value ( $t$ ) of NPL ratio (Bahovec and Erjavec, 2009, 211).

\section{RESULTS}

The GDP growth rates and NPL ratios of both countries and Eurozone are presented in figure 1. Global financial crisis hit Croatia more sharply than Bosnia and Herzegovina and this, together with the weaknesses of the local economy, 
resulted with the economic downturn in 6 years (only 2 in Bosnia and Hercegovina).Comparing the economic trends with the Eurozone, data indicate higher growth rates of Bosnia and Hercegovina than the average of the Euro area for the period observed, while Croatia achieve higher growth only in the 2016 and 2017. Despite difference in the GDP growth rates, trend regarding the NPL ratio is similar for both countries. Firstly, at the beginning the financial crisis, NPL ratio rose significantly in both countries, much higher than in the Eurozone. With the start of the economic recovery, ratio of NPL started decreasing (from 2013 in Bosnia and Herzegovina and 2015 in Croatia), but the level of NPLs is still much higher than in the pre-crisis period and in the Euro area.

Figure 1. GDP growth rates and NPL ratio in Bosnia and Herzegovina, Croatia and Eurozone
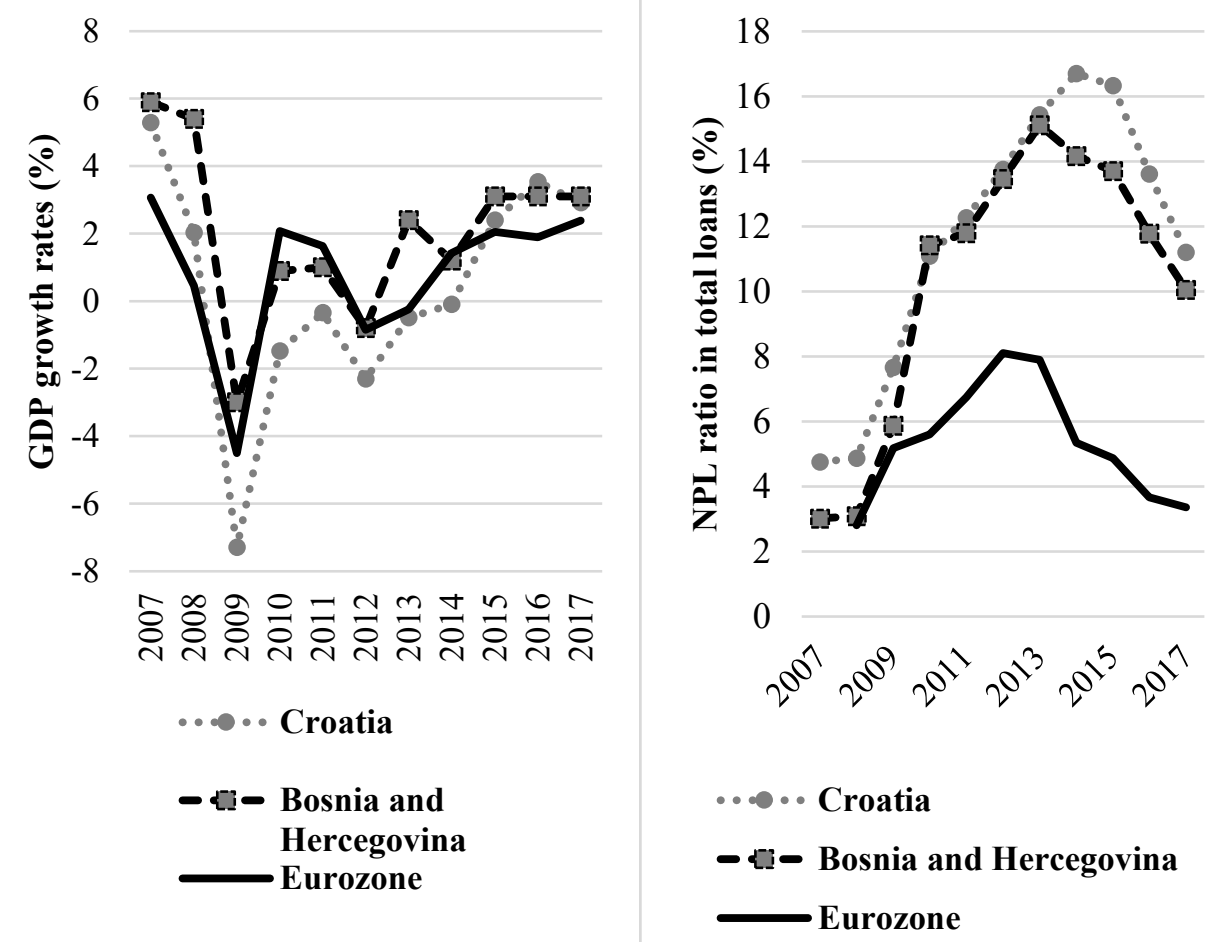

Sources: Prepared based on the database Financial Soundness indicators of the IMF

Regarding statistics of the banking sector, the growth of the banks' assets and loans is much higher in Bosnia and Hercegovina than Croatia (39\% and 56\% in Bosnia and Hercegovina, $13 \%$ and $5 \%$ in Croatia respectively). Therefore, the loan to deposit ratio (LTD) is declining continuously in Croatia since 2008 and is lower by $17 \%$ than at the beginning of the period while in Bosnia and Hercegovina, despite decline in most years, is slightly lower at the end of the observed period. Presented 
data indicate that banks, especially in Croatia, despite high liquidity and capitalization levels, are not eager for intensive lending, with the fear of re-growth of the NPL ratio and the profit losses being one of the key factors. In spite of higher NPL ratios, the Croatian banks are more profitable in the most observed years.

Table 2. The descriptive statistics of banking sectors

\begin{tabular}{|c|c|c|c|c|c|c|c|c|c|c|c|c|}
\hline Country & Variable & 2007 & 2008 & 2009 & 2010 & 2011 & 2012 & 2013 & 2014 & 2015 & 2016 & 2017 \\
\hline \multirow{6}{*}{ Croatia } & Assets* & 47.0 & 51.2 & 51.6 & 53.7 & 54.7 & 53.2 & 52.5 & 51.8 & \begin{tabular}{|l|}
51.7 \\
\end{tabular} & 51.6 & 52.5 \\
\hline & Loans** & 63 & \begin{tabular}{|l|}
67 \\
\end{tabular} & 67 & 68 & 69 & 67 & 66 & 64 & 63 & 61 & 58 \\
\hline & Capitz & 13 & 14 & 14 & 14 & 14 & 14 & 14 & 14 & 13 & 14 & 15 \\
\hline & LTD $^{* * *}$ & 0.93 & 1.00 & 0.98 & 0.99 & 0.99 & 0.97 & 0.93 & 0.88 & \begin{tabular}{|l|}
0.84 \\
\end{tabular} & 0.80 & 0.76 \\
\hline & ROA** & 1.6 & 1.6 & 1.1 & 1.1 & 1.2 & 0.8 & 0.2 & 0.5 & $\mid-1.3$ & 1.6 & 1.0 \\
\hline & $\mathrm{ROE}^{* *}$ & 10.9 & 9.9 & 6.4 & 6.5 & 6.9 & 4.8 & 0.8 & 2.8 & -8.8 & 9.6 & 5.9 \\
\hline \multirow{6}{*}{$\begin{array}{l}\text { Bosnia and } \\
\text { Hercegovina }\end{array}$} & Ass & 10.0 & 10.6 & 10.5 & 10.4 & 10.7 & 10.8 & 11.3 & 11.6 & 12.1 & 12.8 & 13.9 \\
\hline & Loans** & 59 & 67 & 65 & 68 & 70 & 72 & 71 & 70 & 69 & 67 & 66 \\
\hline & Capital** & & & 10.7 & 11.8 & 13.6 & 14.2 & 14.4 & 14.4 & \begin{tabular}{|l|}
14.1 \\
\end{tabular} & \begin{tabular}{|l|}
14.4 \\
\end{tabular} & 14.0 \\
\hline & LTD $^{* * *}$ & 0.97 & 1.22 & 1.17 & 1.16 & 1.18 & 1.19 & 1.15 & 1.08 & \begin{tabular}{|l|}
1.03 \\
\end{tabular} & 0.98 & 0.95 \\
\hline & ROA** & 0.8 & 0.4 & 0.1 & $-0.6 \%$ & 0.7 & 0.7 & $-0.1 \%$ & 0.8 & 0.3 & 1.1 & 1.5 \\
\hline & $\mathrm{ROE}^{* *}$ & 8.6 & 4.2 & 0.8 & $-5.5 \%$ & 5.8 & 5.1 & $-0.5 \%$ & $\overline{5.4}$ & 2.0 & 7.3 & 10.2 \\
\hline
\end{tabular}

* Value in billion $€$

** Percentage of total assets (capital, loans, ROA) or capital (ROE) *** Loan to deposit ratio

Source: Authors' calculation according to the statistics and publications of the central banks and International Monetary Fund

The results of the regression model for both countries are presented in table 3. For Bosnia and Hercegovina results indicate that, at the significance level of $10 \%$, GDP growth rates and unemployment rates are significant variables for the NPL ratio. Surprisingly, the variables tend to show opposite interactions then one should expect by the literature review and intuition: negative effect of the GDP growth rates and positive effect of the rise of the unemployment rates. In the Republic of Croatia, two independent variables, GDP growth rates and amount of loans, are proved significant at the $10 \%$ level. Both variables tend to have negative effect on the NPL ratio, i.e. increase of the GPD growth rate and loans decreases the NPL ratio levels.

Q42008)

Table 3. OLS results for Bosnia and Herzegovina and Croatia (Q12007-

\begin{tabular}{|l|l|l|l|}
\hline Dependent variable: NPL (Bosnia and Herzegovina \\
\hline Variable & Coefficient & Std. Error & t-Statistic (Prob.) \\
\hline Constant & -0.772721 & 4.100149 & $-0.188462(0.8519)$ \\
\hline CPI $_{-2}$ & -0.466959 & 2.415188 & $-0.193343(0.8481)$ \\
\hline GDP-3 $_{-3}$ & 1.731091 & 1.002094 & $1.727473(0.0955)$ \\
\hline UNPL-5 & -2.61862 & 1.316895 & $-1.988481(0.057)$ \\
\hline
\end{tabular}




\begin{tabular}{|l|l|l|l|}
\hline SHARE & 0.237917 & 0.191484 & $1.242490(0.2247)$ \\
\hline AR $(1)$ & 0.383458 & 0.185833 & $2.063452(0.0488)$ \\
\hline $\begin{array}{l}\text { Adj. } R^{2}=0.224886, \text { AIC }=8.187075, \mathrm{SC}=8.501326, \mathrm{HQC}=8.294243, \mathrm{DW}= \\
\text { 2.146892, Prob (F-statistic) }=0.04069\end{array}$ \\
\hline Dependent variable: NPL (Croatia) \\
\hline Variable & Coefficient & Std. Error & t-Statistic (Prob.) \\
\hline Constant & -0.391836 & 2.428672 & $-0.161338(0.8730)$ \\
\hline GDP-4 & -1.183203 & 0.530338 & $-2.231035(0.0339)$ \\
\hline LOAN & -0.577362 & 0.331501 & $-1.741661(0.0925)$ \\
\hline UNPL-1 & 0.425954 & 0.054466 & $-1.187707(0.2449)$ \\
\hline SHARE-4 & -0.064689 & 0.191484 & $1.242490(0.2247)$ \\
\hline AR $(1)$ & 0.583106 & 0.15061 & $3.871638(0.0006)$ \\
\hline $\begin{array}{l}\text { Adj. R } \\
2\end{array}$ 2.170761, Prob $(\mathrm{F}-$-statistic $)=0.00132$ & \\
\hline
\end{tabular}

Subscripts represent number of lags for each variable.

Source: Author's calculation

\section{DISCUSSION}

This study estimated the impact of certain macroeconomic and banking variables on the NPL ratio in Croatia and Bosnia and Herzegovina. Calculated results indicate that GDP growth rate is the only significant variable in both countries. However, the variable has a contradictory effect, where increase of the GDP growth rate is decreasing NPL ratio in Croatia and increasing it in the Bosnia and Herzegovina. This can be partially explained by the chosen variables and model representation which is, according to the Adj. $\mathrm{R}^{2}$ and Prob (F-statistic) much higher and comprehensive in Croatia. Secondly, despite positive GDP growth rates and decrease of the unemployment rates in most observed period in Bosnia and Herzegovina, the NPL ratio grew in the most quarters, similar to the levels in Croatia, country with the worse economic indicator in the observed period. Thus, the results could emphasize the possible impact of additional variables on NPL ratio.

In recent years, the NPL ratio started decreasing in both compared countries. For Bosnia and Herzegovina, this process in 2017 is mostly result of a permanent write off of NPLs, resulting with the reduction of NPLs by 80.5 million $€$ (Central bank of Bosnia and Herzegovina, 2017, 60). The most contributing factor in recent years was a quality of the GDP growth, although better management of the NPLs should not be neglected. To further decrease the NPL ratio, regulatory changes in the current tax law and debt collection and execution are needed which would enable secondary market and speed up court proceedings (Central bank of Bosnia and Herzegovina, 2017, 61).

Similarly to Bosnia and Herzegovina, the decrease of the NPL ratio in Croatia is mostly the result of NPL sale in the secondary market which amounted 
approximately 3.6 billion $€$ from 2010 onwards (Croatian National Bank, 2018, 30 ). This process was boosted in 2014 onwards by the Croatian National Bank with the Decision on the classification of placements and off-balance sheet liabilities of credit institutions (OG 41A/2014)'which forced banks to progressively adjust values of exposures depending on the number of delinquency days and motivated sale of NPLs (Croatian National Bank, 2017, 8). In both countries, the NPL ratio is still higher than the average of CEE countries and further effort is needed to resolve the issue, with possible measures such as better banks' NPL management, improvement of insolvency procedures and more transparent justice system.

Despite much lower NPL ratio then countries in this paper, the NPL ratio is also a great challenge at the level of the EU. Recent global financial crisis and sovereign debt of certain European countries deteriorated banks' balance sheet with the current level of NPLs at 900 billion $€$ and unlikelihood to reach pre-crisis levels in near future (European Banking Authority, 2017, 36). In the EU, as in Croatia, secondary NPL market proved especially important in reducing NPL levels, although with certain market failures, such as not lower bid-ask spreads, which could be resolved with the European Council's NPL Action Plan expected in 2018 and national reforms (European Central Bank, 2018, 100). Recently, in March 2018 European Banking Authority published the 'Draft Guidelines on management of non-performing and forborne exposures' in which it especially emphasises the importance of adequate NPL framework and strategy at the level of individual credit institution (European Banking Authority, 2018, 18).

The model conducted in this research has certain limitations. Firstly, the variables included in the regression and inclusion of additional variables can change the result of any regression analysis. Due to data limitations or unavailability, certain variables which could be significant in determining NPL levels were not included in the model (e.g. currency exchange rates, lending rates). Secondly, despite using quarterly data, initial number of periods in the model is 44 , but is further decreased after the calculation of annual percentage changes and by lagging the independent variables. Regarding lags of variables, different lags yield different results in all regression analysis, although this issue was reduced by using usual criteria to determine relevant number of lags. Finally, more detailed NPL division, i.e. separate ratio of retail and corporate ratios should also be considered in order to better observe and analyse differences between these two sectors and their separate trends. Based on the above mentioned, this research is a base for further more detailed and sophisticated paper.

\section{CONCLUSION}

The ratio of NPLs to total loans is one of the key determinants of banks' business performance, but also its level is one of the key prerequisites for economic stability and growth. The main hypothesis of this paper is that macroeconomic factors, 
especially economic growth, have a key impact on NPL ratio in Bosnia and Herzegovina and Croatia. Results indicate that GDP growth rate is significant in determining NPL ratio in both countries, but with opposite effect. Since both countries in this research have a higher level of NPL ratios than average of the EU or CEE and SEE, better management of banks' loan portfolio and consequently NPLs is one the key challenges in increasing the amount of loans and improvement of the financial intermediation of the banking system. Further research should focus on inclusion of more variables which could impact NPL levels, covering of the longer time period and inclusion of more similar countries in the research.

\section{REFERENCES}

1. Bahovec, V., Erjavec, N., (2009), Uvod u ekonometrijsku analizu, Element d.o.o., Zagreb

2. Bank for International Settlements, (2017), Basel III: Finalising post-crisis reforms, Bank for International Settlements, Basel

3. Chatfield, C., (2003), The Analysis of Time Series: An Introduction, CRC Press, Boca Raton

4. Wooldridge, J.M., (2016), Introductory Econometrics: A Modern Approach, Cengage Learning, Boston

5. Bernanke, B., Gertler, S., Gilchrist, M. (1999), The Financial accelerator in a quantitative business cycle framework, Handbook of Macroeconomics (ed. Tayjor, J.B., Woodford, M.), pp. 1341-1393, Elsevier, Amsterdam

6. Kozarić, K., Žunić, E. (2017), Cointegration Analysis of Non-performing Loans and Macroeconomic Conditions, Finance in Central and Southeastern Europe (ed. Goić, S., Karasavvoglou, A., Polychronidou, P.), pp. 89-102, Elsevier, Amsterdam

7. International Monetary Fund, Financial Soundness Indicators. http://data.imf.org/?sk=51B096FA-2CD2-40C2-8D09-0699CC1764DA (accessed 11 October 2018)

8. Anić., Z., Jeremić, Z., (2018), Macroeconomic and Specific Banking Determinants of Nonperforming loans in Bosnia and Herzegovina, Industrija, Vol. 46, No. 1, pp. 45-60

9. Benazić, M., Radin, D., (2015), Macroeconomic Determinants of the Nonperforming Placements and Off-balance Sheet Liabilities of Croatian Banks, Organizacija, Vol. 48, No. 2, pp. 75-87

10. Beck, R., Jakubik, P., Piloiu, A., (2015), Key Determinants of Nonperforming Loans: New Evidence from a Global Sample, Open Economies Review, Vol. 26, pp. 525-550

11. Bernanke, B., Gertler, M., (1989), Agency Costs, Net Worth, and Business Fluctuations, The American Economic Review, Vol. 79, No. 1, pp. 14-31

12. Dimitrios, A., Helen, L., Mike, T., (2016), Determinants of nonperforming loans: Evidence from Euro-area countries, Finance Research Letters, Vol. 18, pp. 116-119 
13. Ghosh, A., (2015), Banking-industry specific and regional economic determinants of non-performing loans: Evidence from US states, Journal of Financial Stability, Vol. 20, Issue C, pp. 93-140

14. Keeton, W.R., Morris, C. (1987), Why do banks' loan losses differ?, Economic Review, Vol. 72, No. 5, pp. 3-21

15. Kozarić, K., Žunić, E., (2015), Causes and Consequences of NPLs in Bosnia and Hercegovina Banking Sector, Journal of Economic and Social Studies, Vol. 5, No. 1, pp. 127-144

16. Kiyotaki, N., Moore, J., (1997), Credit Cycles, Journal of Political Economy, Vol. 105, No. 2, pp. 211-248

17. Louzis, D.P., Vouldis, A.T., Metaxas, V.L., (2012), Macroeconomic and bank-specific determinants of non-performing loans in Greece: A comparative study of mortgage, business and consumer loan portfolios, Journal of Banking and Finance, No.36, pp. 1012-1027

18. Macháček, M., Melecký, A., Šulganová, M., (2018), Macroeconomic Drivers of Non-Performing Loans: A Meta-Regression Analysis, Prague Economic Papers, Vol. 27, No. 3, pp. 351-374

19. Makri, V., Tsagkanos, A., Bellas, A., (2014), Determinants of NonPerforming Loans: The Case of Eurozone, Panoeconomicus, Vol. 2, pp. 193-206

20. Pašić, S., Omerbegović-Arapović, A., (2016), The Influence of Macroeconomic Trends on the Repayment pf Loans by Households: Evidence from the Federation of Bosnia and Herzegovina and Policy Recommendations, South East European Journal of Economics and Business, Vol. 11, No. 1, pp. 76-87

21. Salas, V., Saurina, J., (2002), Credit Risk in Two Institutional Regimes: Spanish Commercial and Savings Banks, Journal of Financial Services Research, Vol. 22, No. 3, pp. 203-224

22. Škarica, B., (2014), Determinants of non-performing loans in Central and Eastern European countries, Financial Theory and Practise, Vol. 38, No. 1, pp. 37-59

23. Quagliariello, M., (2007), Banks' riskiness over the business cycle: a panel analysis on Italian intermediaries, Applied Financial Economics, Vol. 17, No. 2, pp. 119-138

24. Zhang, D., Cai, J., Dickinson, D.G., Kutan, A.M., (2016), Non-performing loans, moral hazard and regulation of the Chinese commercial banking system, Journal of Banking and Finance, Vol. 63, pp. 48-60

25. Žiković, I.T., Žiković, S., Blecich, A.A., (2015), The Drivers Behind Household and Corporate Non-performing Loans Ratio: The Case of Croatia, Privredna kretanja i ekonomska politika, Vol. 24, No. 2, pp. 7-34

26. Bank for International Settlements, (2017), Basel III: Finalising post-crisis reforms, Bank for International Settlements, Basel

27. Central Bank ofBosnia and Hercegovina, (2017), Financial Stability Report 2017, Central Bank of Bosnia and Hercegovina, Sarajevo 
28. Central Bank of Bosnia and Hercegovina, (2017), Methodology for Compilation of Financial Soundness Indicators, Central Bank of Bosnia and Hercegovina, Sarajevo

29. Croatian National Bank, (2018), Banks Bulletin, Croatian National Bank, Zagreb

30. Croatian National Bank, (2017), Decision on the classification of exposures into risk categories and the method of determining credit losses, Croatian National Bank, Zagreb

31. Croatian National Bank, (2017), Macroprudential Diagnostic: third quarter of 2017, Croatian National Bank, Zagreb

32. Croatian National Bank, (2014), Decision on the classification of placements and off-balance sheet liabilities of credit institutions, Croatian National Bank, Zagreb

33. European Banking Authority, (2018), Draft Guidelines on management of non-performing and forborne exposures, European Banking Authority, London

34. European Banking Authority, (2017), Risk Assessment of the European Banking System, European Banking Authority, London

35. European Banking Authority, (2013), EBA FINAL draft Implementing Technical Standards On Supervisory reporting on forbearance and nonperforming exposures under article 99(4) of Regulation (EU) No 575/2013, European Banking Authority, London

36. European Banking Coordination "Vienna" Initiative, (2012), Working Group on NPLs in Central, Eastern and Southeastern Europe, European Banking Coordination Initiative, Vienna

37. European Central Bank, (2018), Financial Stability Review, European Central Bank, Frankfurt am Main

38. European Systemic Risk Board, (2017), Resolving non-performing loans in Europe, European Systemic Risk Board, Frankfurt am Main

39. International Financial Reporting Standards Foundation, (2014), IFRS 9 Financial Instruments Project Summary, International Financial Reporting Standards Foundation, London

40. International Monetary Fund, (2016), Financial Soundness indicators: Compilation Guide, International Monetary Fund, Washington

41. Klein, N., (2013), Non-Performing Loans in CESEE: Determinants and Macroeconomic Performance, IMF Working Paper 13/72, International Monetary Fund, Washington

42. Nkusu, M., (2011), Nonperforming Loans and Macrofinancial Vulnerabilities in Advanced Economies, IMF Working Paper 11/161, International Monetary Fund, Washington

43. Raiffeisen Research, (2017), CEE Banking Sector Report, Raiffeisen Bank International $\mathrm{AG}, \mathrm{Vienna}$ 